\title{
FORMULASI DAN EFEK ANTI BAKTERI SEDIAAN GEL PENCUCI TANGAN DARI MINYAK ATSIRI DAUN KEMANGI (Occimum basilicum L.) TERHADAP Eschericia coli
} \author{
L.) For Eschericia coli \\ Arisanty*, Tajuddin Abdullah, Muli sukmawaty \\ Jurusan Farmasi Poltekkes Kemenkes Makassar \\ *Email :phuddinkpharm@gmail.com
}

Formulation and Anti-Bacterial Effects Of Hand Washing Gels From Basil Essential Oil (Occimum basilicum

DOI: https://doi.org/10.32382/mf.v15i2.1165

\section{ABSTRACT}

Basil essential oil (Occimum basilicum L.) has inhibitory properties against Escherichia coli (KBM value of $0.25 \%$ ) and therefore has the potential to be used as a handwashing gel. This study aims to formulate the essential oils of basil leaves (Occimum basilicum L.) in the form of a physically stable handwashing gel and test its effectiveness on the growth of Escherichia coli. The gel formula was made using Carbopol base with variations in concentration of $0.1 \%, 0.2 \%, 0.3 \%$ and $0.4 \%$. It was then tested for physical quality strength using the accelerated stability testing method with the Climatic Chamber. The most stable gel formula was tested for its effectiveness against Escherichia coli through the agar diffusion method. The results obtained an average inhibition of gels without and with essential oils of $9.67 \mathrm{~mm}$ and $15.67 \mathrm{~mm}$, respectively. The results of statistical tests showed that the inhibition of handwashing gel with essential oils from the basil leaves (Occimum basilicum L.) was significantly greater than preparations without essential oils ( $p<0.05)$.

Keywords: Gel, basil essential oil, Escherichia coli

\begin{abstract}
ABSTRAK
Minyak atsiri Daun Kemangi (Occimum basilicum L.) memiliki daya hambat terhadap Eschericia coli (Nilai KBM 0,25\%) sehingga berpotensi untuk diformulasi dalam bentuk gel pencuci tangan. Penelitian ini bertujuan untuk memformulasi minyak atsiri daun kemangi (Occimum basilicum L.) dalam bentuk sediaan gel pencuci tangan yang stabil secara fisik dan menguji efektifitas gel tersebut terhadap pertumbuhan Eschericia coli. Formula gel dibuat menggunakan basis Carbopol dengan variasi konsentrasi yaitu $0,1 \%, 0,2 \%, 0,3 \%$ dan $0,4 \%$. Formula gel tersebut kemudian diuji kestabilan mutu fisiknya menggunakan metode pengujian kestabilan dipercepat dengan alat Climatic Chamber. Formula gel yang paling stabil kemudian diuji efektifitasnya terhadap Eschericia coli dengan metode difusi agar. Hasil yang diperoleh daya hambat rata-rata gel tanpa minyak atsiri adalah 9,67 mm sedangkan untuk gel dengan minyak atsiri adalah $15,67 \mathrm{~mm}$. Hasil pengujian statistik menunjukkan daya hambat Gel pencuci tangan dengan minyak atsiri Daun Kemangi (Occimum basilicum L.) signifikan lebih besar dari sediaan tanpa minyak atsiri $(p<0,05)$
\end{abstract}

Kata kunci : Gel, minyak atsiri kemangi, Eschericia coli

\section{PENDAHULUAN}

Tangan merupakan media yang sangat mudah untuk penyebaran penyakit dan infeksi pada manusia karena tangan manusia sangat sering melakukan kontak dengan lingkungan, serta kontak dengan area mata, hidung maupun mulut yang sangat rentan untuk jalan infeksi bakteri. Di negara berkembang seperti Indonesia, penyakit infeksi bakteri masih menyebabkan banyak penyakit bahkan kematian. (Kurniawan dkk, 2012).
Kebersihan tangan yang terjaga adalah salah satu hal penting dalam langkah pencegahan penyakit yang disebabkan oleh infeksi mikroorganisme dan penyakit menular lainnya (WHO,2005).

Hand sanitizer umumnya diformulasikan dalam bentuk sediaan gel yang memberikan sensasi lembut dan nyaman digunakan di kulit (Lubrizol, 2009). Gel merupakan sistem semisolid terdiri dari suspensi yang dibuat dari partikel anorganik kecil atau molekul organik yang besar, terpenetrasi oleh 
suatu cairan(Dirjen POM, 1995). Gel mengandung gelling agent yang berperan menyusun konsistensi sediaan gel. Salah satunya merupakan Carbopol (carbomer) yang membentuk polimer dengan viskositas yang diatur dengan penambahan elektrolit dan pengaturan $\mathrm{pH}$ (Troydan Beringer, 2006). Gel juga mengandung humektan yang berperan menarik air dan memiliki kemampuan meningkatkan hidrasi pada lapisan stratum korneum. Propilen glikol adalah salah satu humektan yang kerap digunakan pada sediaan topikal (Barel dkk, 2014). Untuk mendapatkan gel hand sanitizer yang memiliki sifat fisik yang stabil serta dapat diterima oleh konsumen maka diperlukan proses optimasi komposisi kedua komponen tersebut.

Salah satu tanaman yang mempunyai aktivitas antibakteri adalah kemangi (Ocimum basilicum L.) (Hammer et al., 1999). Hasil penelitian Fauzia, 2007 menunjukkan Kadar Bunuh Minimal (KBM) Minyak Atsiri daunKemangi terhadap Eschericia coli adalah 0,25 $\%$. Kandungan kimia tanaman kemangi yang utama adalah linalool (56,7-60,0\%) yang berpotensi sebagai antibakteri (Telci et al., 2006). Sediaan gel lebih banyak digunakan karena rasa dingin di kulit, mudah mengering dan mudah dicuci. Bahan pembentuk gel yang biasa digunakan adalah HPMC (Suardi et al., 2008).

Berdasarkan uraian tersebut di atas, rumusan masalah adalah apakah minyak atsiri Daun Kemangi (Ocimum basilicum L.) dapat diformulasi dalam bentuk sediaan gel pencuci tangan dan apakah sediaan hasil formulasi tersebut masih memiliki kemampuan antibakteri terhadap Eschericia coli.

Penelitian ini bertujuan untuk menformulasikan sediaan gel pencuci tangan dari minyak atsiri Daun Kemangi (Ocimum basilicum L.) dan menganalisis kestabilan mutu fisik dari gel pencuci tangan yang telah diformulasikan dari minyak atsiri Daun Kemangi (Ocimum basilicum L.) juga untuk menguji kemampuan antibakteri gel pencuci tangan dari minyak atsiri Daun Kemangi (Ocimum basilicum L.) terhadap Eschericia coli.

\section{METODE}

\section{Desain,waktu dan tempat}

Jenis penelitian ini adalah eksperimen laboratorium,yaitu membuat sediaan gel pencuci tangan pencuci tangan dari minyak atsiri daun kemangi (Ocimum basilicum) dengan pengujian sifat fisik dan stabilitas serta pengujian antibakteri terhadap Eschericia coli dengan metode difusi agar.

Penelitian ini dilaksanakan di laboratorium Farmasetika dan Laboratorium Mikrobiologi Jurusan Farmasi Politeknik Kesehatan Kemenkes Makassar pada bulan Juli hingga September 2018

\section{Alat dan bahan}

Alat yang digunakan batang pengaduk,bejana maserasi,beaker gelas $500 \mathrm{ml}$, erlenmeyer,gelas ukur $50 \mathrm{ml}$, gelas ukur 100 ml,kertas ph, lumpang, objek glass, penangas air, stamper, timbangan analitik, wadah gel. Bahan yang digunakan Minyak atsiri daun kemangi (Ocimum basilicum L), carbomer 940, tea, alcohol $70 \%$, metal paraben, gliserin,dan aquadest. Bakteri uji yang digunakan adalah Eschericia coli

\section{Prosedur Penelitian}

\section{Pembuatan sediaan gel pencuci tangan pencuci tangan. \\ Pembuatan gel hand sanitizer menurut} Shu(2013), mortir dan stamper disiapkan. Carbopol ditimbang dan ditaburkan diatas aquades $20 \mathrm{~mL}$ yang sudah dipanaskan. Carbopol yang sudah ditaburkan diaduk cepat di dalam mortar sampai terbentuk masa gel dan ditambahkan TEA. Metil paraben dilarutkan dalam aquades panas, dimasukkan ke dalam mortir, diaduk sampai homogen. Minyak atsiri daun kemangi ditimbang dan dilarutkan bersama propilenglikol secara bertahap. Minyak atsiri daun kemangi yang sudah larut dimasukkan ke dalam mortir, dicampur sampai homogen dan digerus sampai terbentuk gel dan diaduk sampai homogen.

\section{Pengujian Mutu Fisik Sediaan Gel pencuci} tangan Tangan Minyak atsiri Daun Kemangi

Pada pembuatan gel, hal yang perlu diperhatikan adalah stabilitas. Stabilitas merupakan kemampuan suatu produk obat atau kosmetik untuk bertahan dalam spesifkasi yang diterapkan sepanjang periode penyimpanan dan penggunaan, untuk menjamin identitas, kekuatan, kualitas dan kemurnian produk (Sri, 2014). Pengujian ini meliputi :

\section{Uji Organoleptis}

Uji organoleptis dilakukan secara visual terhadap sediaan gel, meliputi warna, bau dan bentuk gel, mudah dioleskan, dan tidak mengandung butiran-butiran kasar. Skala penilaian 
1-4 sebagai berikut: 1 (tidak sesuai), 2 (kurang sesuai), 3 (sesuai), 4 (sangat sesuai).

\section{Uji pH}

Sampel ditimbang sebanyak 1 gram. Sebanyak $10 \mathrm{~mL}$ aquad $\mathrm{pH} 7$ di tambahkan, lalu dilakukan pengadukan. Setelah homogen dilakukan pengukuran $\mathrm{pH}$ dengan cara masukan pH meter yang telah di kalibrasi, didiamkan beberapa saat sehingga didapat $\mathrm{pH}$ yang tetap.

\section{Homogenitas}

Pemeriksaan homogenitas sediaan dapat dilakukan dengan cara, sediaan dioleskanpada dua keping kaca atau bahan transparan lain yang cocok, sediaan harus menunjukan susunan yang homogen dan tidak terlihat adanya butiran kasar (Ditjen POM, 2000).

\section{Sineresis}

Sineresis yang terjadi selama penyimpanan diamati dengan menyimpan gel pada suhu $\pm 10^{\circ} \mathrm{C}$ selama 24,48 dan 72 jam. Masingmasing gel ditempatkan pada cawan untuk menampung air yang dibebaskan dari dalam gel selama penyimpanan. Sineresis dihitung dengan mengukur kehilangan berat selama

\section{Pengujian Efek Antibakteri sediaan gel pencuci tangan}

Pengujian efek antibakteri sediaan gel pencuci tangan minyak atsiri Daun Kemangi dengan mutu fisik terbaik dilakukan terhadap Eschericia coli dengan metode difusi agar menggunakan kertas cakram dengan cara Kertas cakram direndam dalam sediaan gel pencuci tangan dengan konsentrasi gelling agent yang menghasilkan gel dengan stabilitas terbaik berdasarkan pengujian, untuk kontrol negatif digunakan basis gel tanpa sampel. Perendaman dilakukan selama \pm 15 menit. Kertas cakram kemudian diangkat lalu diletakkan secara aseptis pada permukaan medium uji Mueller Hilton Agar yang sudah setengah memadat. Jarak antara kertas cakram dari tepi cawan sekitar 2-3 cm, medium dibiarkan memadat. Lalu diinkubasi pada suhu $37^{\circ} \mathrm{C}$ selama 1 x 24 jam. Perlakuan diulangi sebanyak 3 kali. Setelah 24 jam diamati dan diukur zona hambat yang terbentuk di sekitar kertas cakram

\section{Analisis Data}

Data hasil pengujian mutu fisik sediaan dan hasil pengujian mikrobiologis kemudian dianalisis secara statistik.

\section{HASIL}

Hasil penelitan yang diperoleh semua formula gel berbentuk cairan agak kental dan berwarna opaq. Konsistensi gel tidak berubah setelah uji stabilitas dipercepat. Pada pengujian $\mathrm{pH}$ diperoleh hasil formula I dan II sebelum dan sesudah penyimpanan tidak terjadi kenaikan $\mathrm{pH} 6$ menjadi $\mathrm{pH} 7$, dan pada formula II dan III dan IV terjadi perubahan $\mathrm{pH}$. Pada uji homogenitas gel tidak berubah sebelum dan setelah uji kestabilan dipercepat. Pada keempat formula terjadi sineresi setelah uji kestabilan dipercepat, kecuali pada formula I. Pada pengujian efek antibakteri didapatkan hasil rata-rata zona hambat untuk Basis carbopol $0,1 \%$ adalah 9,67 mm sedangkan untuk gel minyak atsiri daun kemangi dengan basis carbopol dihasilkan zona hambat rata-rata 15,67 $\mathrm{mm}$. Hasil dapat dilihat pada tabel dibawah ini

Tabel 1. Rancangan Formula sediaan gel minyak atsiri daun kemangi (Ocimum basilicum L.)

\begin{tabular}{lcccc}
\hline \multirow{2}{*}{ Nama zat } & \multicolumn{4}{c}{ Konsentrasi (gram) } \\
\cline { 2 - 5 } & F1 & F2 & F3 & F4 \\
\hline Minyak atsiri Daun kemangi & $1 \%$ & $1 \%$ & $1 \%$ & $1 \%$ \\
Carbopol & $\mathbf{0 , 1 \%}$ & $\mathbf{0 , 2 \%}$ & $\mathbf{0 , 3 \%}$ & $\mathbf{0 , 4 \%}$ \\
Trietanolamin & $2 \%$ & $2 \%$ & $2 \%$ & $2 \%$ \\
Propilenglikol & $10 \%$ & $10 \%$ & $10 \%$ & $10 \%$ \\
Metil paraben & $0,18 \%$ & $0,18 \%$ & $0,18 \%$ & $0,18 \%$ \\
Aquadest & ad 30 g & ad 30 g & ad 30 g & ad 30 g \\
\hline
\end{tabular}


Tabel 2. Formula sediaan gel handsanitizer minyak atsiri kemangi (Ocimum Basilicum L.)

\begin{tabular}{lcccc}
\hline \multirow{2}{*}{ Nama zat } & \multicolumn{3}{c}{ Konsentrasi (gram) } \\
\cline { 2 - 5 } & $\mathrm{F} 1$ & $\mathrm{~F} 2$ & $\mathrm{~F} 3$ & $\mathrm{~F} 4$ \\
\hline Minyak atsiri Daun kemangi & $1 \%$ & $1 \%$ & $1 \%$ & $1 \%$ \\
Carbopol & $0,1 \%$ & $0,2 \%$ & $0,3 \%$ & $0,4 \%$ \\
Trietanolamin & $2 \%$ & $2 \%$ & $2 \%$ & $2 \%$ \\
Propilenglikol & $10 \%$ & $10 \%$ & $10 \%$ & $10 \%$ \\
Metil paraben & $0,18 \%$ & $0,18 \%$ & $0,18 \%$ & $0,18 \%$ \\
Pewarna & $0,1 \%$ & $0,1 \%$ & $0,1 \%$ & $0,1 \%$ \\
Aquadest & ad 30 g & ad 30 g & ad 30 g & ad 30 g \\
\hline
\end{tabular}

Tabel 3. Hasil pengujian organoleptis sediaan gel handsanitizer minyak atsiri kemangi (Ocimum Basilicum L.)

\begin{tabular}{|c|c|c|c|c|}
\hline \multirow{2}{*}{\multicolumn{2}{|c|}{ Formula }} & \multicolumn{3}{|c|}{ Uji organoleptik } \\
\hline & & Bentuk & Warna & $\mathrm{Bau}$ \\
\hline \multirow{2}{*}{ Formula I } & $\begin{array}{l}\text { Sebelum } \\
\text { pengujian }\end{array}$ & $\begin{array}{l}\text { Cairan } \\
\text { agak } \\
\text { kental }\end{array}$ & $\begin{array}{l}\text { Hijau } \\
\text { Opaq }\end{array}$ & $\begin{array}{l}\text { Khas } \\
\text { kemangi }\end{array}$ \\
\hline & $\begin{array}{l}\text { Setelah } \\
\text { pengujian }\end{array}$ & $\begin{array}{l}\text { Cairan } \\
\text { agak } \\
\text { kental }\end{array}$ & $\begin{array}{l}\text { Hijau } \\
\text { Opaq }\end{array}$ & $\begin{array}{l}\text { Khas } \\
\text { kemangi }\end{array}$ \\
\hline \multirow{2}{*}{ Formula II } & $\begin{array}{l}\text { Sebelum } \\
\text { pengujian }\end{array}$ & $\begin{array}{l}\text { Cairan } \\
\text { agak } \\
\text { kental }\end{array}$ & $\begin{array}{l}\text { Hijau } \\
\text { Opaq }\end{array}$ & $\begin{array}{l}\text { Khas } \\
\text { kemangi }\end{array}$ \\
\hline & $\begin{array}{l}\text { Setelah } \\
\text { pengujian }\end{array}$ & $\begin{array}{l}\text { Cairan } \\
\text { agak } \\
\text { kental }\end{array}$ & $\begin{array}{l}\text { Hijau } \\
\text { Opaq }\end{array}$ & $\begin{array}{l}\text { Khas } \\
\text { kemangi }\end{array}$ \\
\hline \multirow{2}{*}{ Formula III } & $\begin{array}{l}\text { Sebelum } \\
\text { pengujian }\end{array}$ & $\begin{array}{l}\text { Cairan } \\
\text { agak } \\
\text { kental }\end{array}$ & $\begin{array}{l}\text { Hijau } \\
\text { Opaq }\end{array}$ & $\begin{array}{l}\text { Khas } \\
\text { kemangi }\end{array}$ \\
\hline & $\begin{array}{l}\text { Setelah } \\
\text { pengujian }\end{array}$ & $\begin{array}{l}\text { Cairan } \\
\text { agak } \\
\text { kental }\end{array}$ & $\begin{array}{l}\text { Hijau } \\
\text { Opaq }\end{array}$ & $\begin{array}{l}\text { Khas } \\
\text { kemangi }\end{array}$ \\
\hline \multirow{2}{*}{ Formula IV } & $\begin{array}{l}\text { Sebelum } \\
\text { pengujian }\end{array}$ & $\begin{array}{l}\text { Cairan } \\
\text { agak } \\
\text { kental }\end{array}$ & $\begin{array}{l}\text { Hijau } \\
\text { Opaq }\end{array}$ & $\begin{array}{l}\text { Khas } \\
\text { kemangi }\end{array}$ \\
\hline & $\begin{array}{l}\text { Setelah } \\
\text { pengujian }\end{array}$ & $\begin{array}{l}\text { Cairan } \\
\text { agak } \\
\text { kental }\end{array}$ & $\begin{array}{l}\text { Hijau } \\
\text { Opaq }\end{array}$ & $\begin{array}{l}\text { Khas } \\
\text { kemangi }\end{array}$ \\
\hline
\end{tabular}

Tabel 4. Hasil pengujian pH sediaan gel handsanitizer minyak atsiri kemangi (Ocimum Basilicum L.)

\begin{tabular}{lccc}
\hline & & \multicolumn{2}{c}{ Uji pH } \\
\cline { 3 - 4 } No & Formula & Sebelum pengujian & $\begin{array}{c}\text { Sesudah } \\
\text { pengujian }\end{array}$ \\
\hline 1 & Formula I & 6 & 6 \\
2 & Formula II & 6 & 6 \\
3 & Formula III & 6 & 7 \\
4 & Formula IV & 6 & 7 \\
\hline
\end{tabular}


Tabel 5. Hasil pengujian homogenitas sediaan gel handsanitizer minyak atsiri daun kemangi

\begin{tabular}{cccc}
\multicolumn{2}{c}{ (Ocimum Basilicum L. $)$} & \multicolumn{2}{c}{ Uji homogenitas } \\
\cline { 3 - 4 } No & Formula & $\begin{array}{c}\text { Sebelum } \\
\text { pengujian }\end{array}$ & $\begin{array}{c}\text { Sesudah } \\
\text { pengujian }\end{array}$ \\
\hline 1 & Formula I & Homogen & Homogen \\
2 & Formula II & Homogen & Homogen \\
3 & Formula III & Homogen & Homogen \\
4 & Formula IV & Homogen & Homogen \\
\hline
\end{tabular}

Tabel 6. Hasil pengujian sineresis sediaan gel handsanitizer minyak atsiri kemangi (Ocimum Basilicum L.)

\begin{tabular}{llll}
\hline \multirow{2}{*}{ No } & Formula & \multicolumn{2}{c}{ Uji Sineresis } \\
\cline { 3 - 4 } & & Sebelum pengujian & Sesudah pengujian \\
\hline 1 & Formula I & Tidak Terjadi sinersis & Tidak Terjadi sinersis \\
2 & Formula II & Tidak Terjadi sinersis & Terjadi sinersis \\
3 & Formula III & Tidak Terjadi sinersis & Terjadi sinersis \\
4 & Formula IV & Tidak Terjadi sinersis & Terjadi sinersis \\
\hline
\end{tabular}

\section{PEMBAHASAN}

Eschericia coli merupakan salah satu bakteri yang sebenanya merupakan flora normal pada saluran GI manusia, namun apabila jumlahnya berlebih dalam tubuh dapat memicu diare. Diare yang disebabkan oleh bakteri tersebut dapat dicegah dengan menerapkan prilaku hidup bersih dan sehat yaitu dengan membiasakan cuci tangan.

Kendala yang dihadapi dalam menerapkan kebiasaan cuci tangan adalah tidak praktisnya karena dibutuhkan air untuk mencuci. Untuk itu dibuatlah formula gel pencuci tangan pencuci tangan. Dalam penelitian ini dibuat gel pencuci tangan dari minyak atsiri daun kemangi. Telah banyak penelitian ilmiah yang dilakukan untuk mengetahui khasiat dari minyak atsiri kemangi, salah satunya adalah penelitian Fauzia pada tahun 2007 menunjukkan Kadar Bunuh Minimal (KBM) Minyak Atsiri daun Kemangi terhadap Eschericia coli adalah 0,25\%. Kandungan kimia tanaman kemangi yang utama adalah linalool $(56,7-60,0 \%)$ yang berpotensi sebagai antibakteri (Telci et al., 2006).

Antiseptik tangan dalam bentuk sediaan gel sangat praktis digunakan. Gel antispetik tangan merupakan sediaan yang berbentuk gel yang digunakan untuk mengurangi atau menghambat pertumbuhan mikroorganisme tanpa membutuhkan air (Girou et al.,2002). Cara pemakaiannya adalah dengan diteteskan pada telapak tangan, kemudian diratakan pada permukaan tangan tanpa dibilas dengan air (Sari \& Isadiartuti, 2006).

Tuwaidan, 2018 telah melakukan penelitian untuk menentukan basis gel yang digunakan dalam formula gel pencuci tangan tangan dari minyak atsiri daun kemangi, dan hasilnya adalah gel dengan basis carbopol menunjukkan kestabilan fisik yang lebih baik dengan tampilan gel yang lebih bening dibandingkan apabila menggunakan basis lain.

Pada penelitian ini digunakan basis carbopol dengan variasi konsentrasi. Sebelumnya pada tahap optimasi formula digunakan satu konsentrasi saja yaitu 0,5 \% namun gel yang dihasilkan terlalu kental dan menyulitkan untuk dituang, sehingga dirasa tidak sesuai untuk jenis sediaan gel pencuci tangan tangan. Karena itu dibuat empat variasi konsentrasi carbopol yaitu $0,1 \%, 0,2 \%, 0,3 \%$ dan $0,4 \%$. Bahan lain yang digunakan dalam formula yaitu Triethanolamin untuk menstabilkan $\mathrm{pH}$, sebab penggunaan carbopol akan menyebabkan $\mathrm{pH}$ sediaan turun dan tidak memenuhi persyaratan $\mathrm{pH}$ sediaan untuk kulit. Propilenglikol ditambahkan dalam formula berfungsi sebagai humektan, selain itu propilenglikol dapat berfungsi sebagai kosolven sehingga minyak atsiri daun kemangi dapat lebih 
bercampur dengan pembawa air yang berjumlah banyak dalam formula. Metil paraben dalam formula gel pencuci tangan tangan ini berfungsi sebagai pengawet, ditambahkan pula pewarna untuk memperkuat kesan psikologis sediaan dan meningkatkan tampilan sediaan.

Formula dibuat dengan cara mencampurkan basis gelling agent yang telah ditambahkan nipagin sebagai zat pengawet yang digunakan dengan minyak atsiri daun kemangi dan dengan basis carbopol dengan penambahan trietanolamin. Evaluasi mutu fisik sediaan handsanitizer gel minyak atsiri daun kemangi dilakukan sebelum dan sesudah penyimpanan untuk menentukan kestabilan mutu fisik. Kestabilan mutu fisik dilakukan dengan metode freeze thaw yaitu dengan menempatkan sediaan gel pada suhu beku kemudian sediaan gel dipindahkan lagi pada suhu kamar menggunakan alat climatic chamber. Pengujian mutu fisik meliputi pemeriksaan organoleptis, pengukuran $\mathrm{pH}$, homogenitas, dan sineresis. Formula dengan mutu fisik paling stabil kemudian diuji lanjutan dengan pengujian mikrobiologi untuk menentukan daya hambatnya terhadap Eschericia coli dengan metode difusi agar.

Uji $\mathrm{pH}$ dilakukan pada setiap formula dengan tujuan untuk melihat tingkat keasaman sediaan gel untuk menjamin sediaan gel tidak menyebabkan iritasi pada kulit. Pengukuran $\mathrm{pH}$ dilakukan dengan menggunakan $\mathrm{pH}$ meter dengan kriteria pH kulit yakni 4,5 - 6,5. Hasil data menunjukkan bahwa $\mathrm{pH}$ keempat formulasebelum pengujian kestabilan dipercepat adalah 6, sedangkan setelah pengujian kestabilan dipercepat $\mathrm{pH}$ dari formula I dan II tidak berubah, sedangkan $\mathrm{pH}$ formula III dan IV naik menjadi 7, sehingga tidak lagi memenuhi persyaratan uji $\mathrm{pH}$ untuk sediaan kulit.

Sineresis merupakan peristiwa gel mengerut secara alamiah dan menyebabkan air di dalam gel akan terperas keluar ke permukaan gel (Bhasha, 2013). Pengujian Sineresis dilakukan untuk mengamati secara visual apakah terbentuk lapisan cairan dipermukaan gel setelah penyimpanan dengan kondisi dipercepat sehingga gel mengerut atau mengeras. Hasil pengujian dapat dilihat pada tabel 6 , yaitu tidak terjadi sineresis sebelum dan setelah pengujian dipercepat pada formula I, sedangkan pada formula lain terjadi sineresis. Adapun faktor yang mempengaruhi ada tidaknya sineresis adalah gelling agent. Lamanya penyimpanan dapat meningkatkan jumlah ikatan silang antar molekul, sehingga pelarut air yang terdapat di dalam gel akan semakin terjerap dalam gelling agent (Suyudi, 2014).

Pengujian stabilitas dipercepat gel pencuci tangan minyak atsiri kemangi menggunakan alat climatic chamber dengan metode freeze thaw yakni menempatkan sediaan gel pada suhu dingin $\left(5^{\circ} \mathrm{C}\right)$ selama \pm 4 jam, kemudian sediaan gel dipindahkan lagi pada suhu panas $\left(35^{\circ} \mathrm{C}\right)$ selama \pm 4 jam percobaan dilakukan sebanyak 5 kali siklus. Pengujian ini dilakukan untuk mengamati kestabilan mutu fisik sediaan. Dari hasil pengujian (Tabel 3-6 terlihat bahwa Formula dengan kestabilan mutu fisik terbaik adalah Gel pencuci tangan minyak atsiri Daun Kemangi dengan basis Carbopol 0,1\%.

Formula I yaitu gel pencuci tangan minyak atsiri daun kemangi dengan basis carbopol $0,1 \%$ diuji efektifitasnya terhadap pertumbuhan Eschericia coli dengan metode difusi agar. Zona hambat diukur setelah inkubasi selama 24 jam setelah paper disk steril direndam dalam sampel selama kurang lebih 15 menit dan dilatekkan secara aseptis di atas medium yang memadat. Hasil pengujian terlihat pada tabel 7 yaitu zona hambat rata-rata basis gel carbopol 0,1\% adalah 9,67 mm dan $15,67 \mathrm{~mm}$ untuk formula gel pencuci tangan minyak atsiri daun kemangi dengan basis carbopol $0,1 \%$. Hasil pengujian statistik menggunakan uji t Paired samples Test menunjukkan signifikansi $0,011<0,05$ pada taraf kepercayaan $95 \%$. Berarti Ho ditolak, ada perbedaan signifikan pada daya hambat Gel pencuci tangan minyak atsiri dengan Basis gel yang digunakan.

\section{KESIMPULAN}

Berdasarkan hasil penelitian dan pembahasan yang telah diuraikan, maka dapat disimpulkan bahwa Gel pencuci tangan minyak atsiri daun kemangi dengan kestabilan mutu fisik terbaik diperoleh apabila menggunakan basis Carbopol 0,1\% sebagai basis. Terdapat perbedaan signifikan antara efektifitas Gel pencuci tangan minyak atsiri daun kemangi dengan Basis carbopol $0,1 \%$ dan Basis carbopol $0,1 \%$ dalam menghambat pertumbuhan Eschericia coli.

\section{SARAN}

Berdasarkan hasil dan pembahasan maka dapat disarankan Disarankan agar sediaan gel dibuat dengan penambahan alkohol untuk memperoleh daya antibakteri yang lebih besar juga perlu dilakukan penelitian lebih lanjut untuk 
mengetahui efektifitas atau daya hambat sediaan gel handsanitizer minyak atsiri daun kemangi terhadap bakteri lain misalnya Staphylococcus aureus.

\section{UCAPAN TERIMA KASIH}

Ucapan terima kasih kepada Poltekkes Kemenkes Makassar yang telah memfasilitasi terlaksananya penelitian ini.

\section{DAFTAR PUSTAKA}

Aiello, Allison E. 2010. Mask use, hand hygiene, and seasonal influenza-like illness among young adults: $A$ randomized intervention trial. J Infect Dis., 201(4): 491-498

Alfitri, 2011. Community Development, Teori dan Aplikasi. Pustaka Pelajar,Yogyakarta.

Barel, O., Paye, M., Maibach, H.I., 2014, Handbook of Cosmetic Science and Technology,Fourth Edition, Taylor \& Francis, United States, 98.

Bilal, Alia et al, 2012, Phytochemical and Pharmacological Studies on Ocimum basilicum Linn-A Review, IJCRR, 4 (23), 73-83.

Dirjen POM, 1995, Farmakope Indonesia, edisi IV, Departemen Kesehatan Republik Indonesia, Jakarta, 7.

Dryer D.L., et al., 1998,Testing a New Alcohol Free Hand Sanitizer to Combat Infection, AORN Journal, Vol. 68, No. 4, 239-251.

Fauzia, R.S., 2007. Uji Aktivitas Antibakteri Minyak Atsiri Daun Kemangi (Occimum basilicum L.) Terhadap Staphylococcus aureus dan Eschericia coli, Skripsi. Fakultas Farmasi Universitas Muhammadiyah Surakarta.

Fisher, K., Phillips, C.A., 2006, The Effect of Lemon, Orange, and Bergamot essential Oils and Their Components on the Survival of Campylobacter jejuni, Escherichia coli 0157, Listeria monoctygenes, Bacillus cereus, and Staphylococcus aureus in vitro and in Food Systems, Journal of Applied Microbiology, 101(6), 1232-1240.

Girou, Emmanuelle. 2002. Efficacy of handrubbing with alcohol based solution versus standard handwashing with antiseptic soap: randomised clinical trial. British Medical Journal, 325.

Hammer, K. A., Carson, C. F., \& Riley, T. V., 1999, Antimicrobial Activity of Essential Oil and Other Plant Extracts, Journal of Applied Microbiology, 86, 985-990.

Kurniawan, D.W., Wijayanto, B.A., Sobri, I., 2012, Formulation and Effectiveness of Antiseptic Hand Gel Preparations Essential Oils Galanga (Alpinia galanga), Asian Journal of Pharmaceutical and Biological Research, 2(4).

Kumari P.R.T.P., SundarS.K., dan Vijayalakshmi A.B., 2014,GC MS analysis and antibacterial activity of Myristica fragrans seed extracts against lower respiratory tract pathogen Acinetobacter baumanii,Asian Journal of Pharmaceutical and Clinical Research, 7(3), pp.126-129.

Larson, Elaine L. 2005. Hand Hygiene Behavior in a Pediatric Emergency Department and a Pediatric Intensive Care Unit: Comparison of Use of 2 Dispenser Systems. Am J Crit Care, 14(4): 304-31.

Lubrizol Corporation, 2009,Formulating Hydroalcoholic Gels with Carbopol Polymers: Technical Data Sheet, Lubrizol Advanced material Inc., Ohio, 16.

Mithun A.T., Udugade B.V., Manoj, B. and Pawade D.A., 2015,Formulation and Evaluation of Novel Herbal Hand Sanitizer, Indo American Journal of Pharmaceutical Research, 5 (01), pp. 483487.

Miller, Michael A. 2006. Does the clinical use of ethanol-based hand sanitizer elevate blood alcohol levels? A prospective study. The American Journal of Emergency Medicine, 24(7): 815-817.

Myers, Ronnie. 2008. Hand Hygiene Among General Practice Dentists A Survey of Knowledge, Attitudes and Practices. The Journal of the American Dental Association, 139: 948-957.

Nurcahyanti, A.D.R., Dewi, L. dan Timotius, K.H. (2011). Aktivitas antioksidan dan antibakteri ekstrak polar dan non polar biji selasih (Ocimum basilicum Linn). Jurnal 
Teknologi dan Industri Pangan 1(XXII): 16.

Putra, H. H., Wibowo, M. H., Untari, T. dan Kurniasih (2012) Studi lesi makroskopis dan mikroskopis embrio ayam yang diinfeksi virus Newcastle Disease isolat lapang yang virulen. J. S. V. 30: 57-67.

Retnosari, Isadiartuti, D., 2006, Studi Efektivitas Sediaan Gel pencuci tangan Tangan Ekstrak Daun Sirih (Piper betle Linn.), Majalah Farmasi Indonesia, 17(4), 163-169.

Romano, L. Battaglia, F., Masucci, L.,Sanguinetti, M., Posteraro, B., Plotti, G., et al.,2005, In Vitro Activity of Bergamot Natural Essence and Furocoumarin-free and Distilled Extracts, and Their Associations with Boric Acid, against Clinical Yeast Isolates, J. Antimicrobial Chemother, 55, 110-114.

Schueller, R., Romanowski, P., 1999, Conditioning Agents for Hair and Skin, Marcell Dekker Inc., New York, 97-102.
Simonne, A., 2005, Hand Hygiene and Hand Sanitizers, IFAS Extension University of Florida, 2-3.

Suardi, M., Armenia, \& Maryawati, A., 2008, Formulasi dan Uji Klinik Gel Anti Jerawat Benzoil Peroksida-HPMC, Fakultas Farmasi FMIPA Universitas Andalas,Padang, 1-3. 14.

Telci, I., Bayram, E., Yilmaz, G., \& Avci, B., 2006, Variability in Essential Oil Composition of Turkish Basils (Ocimum basilicum L), Biochemical Systemic Ecology, 34, 489-497.

Traore, O., Hugonnet,S., Lubbe, J., Griffiths, W., Pittet, D.,2007, Liquid versus Gel Handrub Formulation : a Prospective Intervention Study, Critical Care, 11(3), 1-8.

World Health Organization, 2005, Guidelines for Hand Hygiene in Health Care, Global Patient Safety Challenge, USA, 12-23. 